\title{
住居集合地域等における麻酔銃猟許可に関する獣医師の今後
}

\author{
森光由樹* \\ 兵庫県立大学自然・環境科学研究所 / 森林動物研究センター ₹ 669-3842 兵庫県丹波市青垣町沢野 940
}

[2015 年 10 月 6 日受領，2016 年 9 月 4 日採択］

\begin{abstract}
要 約
野生動物と人との軒轁は，農業被害だけにとどまらず，近年は「人家侵入」，「器物の破壊」および「人への威嚇」な ぞ, 生活被害や人身被害にまで拡大し始めている。これらの動物を捕獲する場合，まず猟銃による捕獲が考えられるが， 「鳥獣の保護及び狩編の適正化に関する法律」並びに「銃刀法」などの規制から市街地で発砲し捕獲することはできない。 そこで，猟銃に比べて極めて威力が小さく，器物破損等の恐れがほとんどない麻酔銃による捕獲が法律改正により使用 可能となった。麻酔銃捕獲は，安全な捕獲法ではある。しかし，いくつか課題がある。麻酔銃を所持するには，管轄す る都道府県公安委員会（警察）から審査を受けて許可を受けねばならない。また，ガンロッカー等頑丈な保管庫で管理 する必要もある。年 1 回，管轄する警察署による銃検査が行われ使用実績や管理状況について報告する義務が生じる。 その一方で麻酔銃は産業銃であるため, 猟銃の所持には必要な筆記試験と実技試験が課せられず，銃の基本的な扱いを 修得していない者であっても警察の審査さえ通れば所持可能である。安易な導入と使用により, 思わぬ事故が誘発され るおそれもある。以上のことから，改正法における麻醉銃の位置づけや運用には，その特徴に起因する様々な問題点の 整理と留意とが不可欠と考えられる。

キーワード:アーバンワイルドライフ, 住居集合地域, 鳥獣の保護及び管理並びに狩猟の適正化に関する法律, 麻酔銃, 野生動物捕獲
\end{abstract}

一日本野生動物医学会誌 21(3)：91-96，2016

\section{住居集合地域等において麻酔銃捕獲が 認められるようになった経緯}

近年，野生動物による生活被害の報告が急増している。発生 場所は，これまで農村部が主であったが，都市部へ広がりつつ ある（図 1）。都市型野生動物（urban wildlife）による被害は 主に「人家侵入」,「器物の破壊」,「人への威嚇」および「咬傷 被害」などである。2016 年 1 月大阪府泉南市で発生した二 ホンザル Macaca fuscata の咬傷被害, 2010 年 8 月, 静岡県 三島市住宅地を徘徊し住民に咬傷被害を繰り返し発生させた二 ホンザルの咬傷被害, 2010 年 10 月，北海道斜里町の商店街 を徘徊したエゾヒグマUrsus arctos yesoensis, 2014 年 4 月, 兵庫県神戸市住宅街で住民に咬傷を繰り返すニホンイノシシ Sus scrofa などが，マスコミ等で報道され有名である。同じよ うな被害は日本全国で多く発生している。これらの都市部へ侵 入した野生動物の対処方法は，行政職員や警察官による追い払

*責任著者：森光由樹（E-mail: morimitsu@wmi-hyogo.jp）
いや網などによる捕獲対応が主であった。しかし野生動物を捕 獲することは難しく，捕獲が長期化し問題を大きくすることが 多かった。猟銃による捕獲が最も効果的に思えるが, これまで, 「鳥獣の保護及び狩編の適正化に関する法律」並びに「銃砲刀 剣類所持等取締法」（以下，銃刀法）などの規制から市街地で 猟銃を発砲し捕獲することはできなかった。こうした事態を踏 まえて,クマなど大型野生動物において人身事故を防ぐため「警 察官職務執行法第 4 条第 1 項（例規通達 2012 年 5 月 1 日）」 により，市街地に拈いて猟銃発射が緊急手段として認められる ようになった $[1]$ 。しかし,ニホンザルなど中型の動物では「警 察官職務執行法」による編銃捕獲は，1）クマ類と比べて死亡 事故を発生することが少ない，2）住居集合地域での猟銃の発 射は，住宅，建造物や器物を破壊する恐れもある，3）広範囲 な安全確認が必要などの理由から,許可されることはなかった。 そこで, 䋃銃に比べて極めて弾の発射威力が小さく, 器物破損 等の恐れが少ない麻酔銃を用いた捕獲が検討された。

2014 年「鳥獣の保護及び狩編の適正化に関する法律」の一 部が改正され，管理という名称が加わり「鳥獣の保護及び管理 


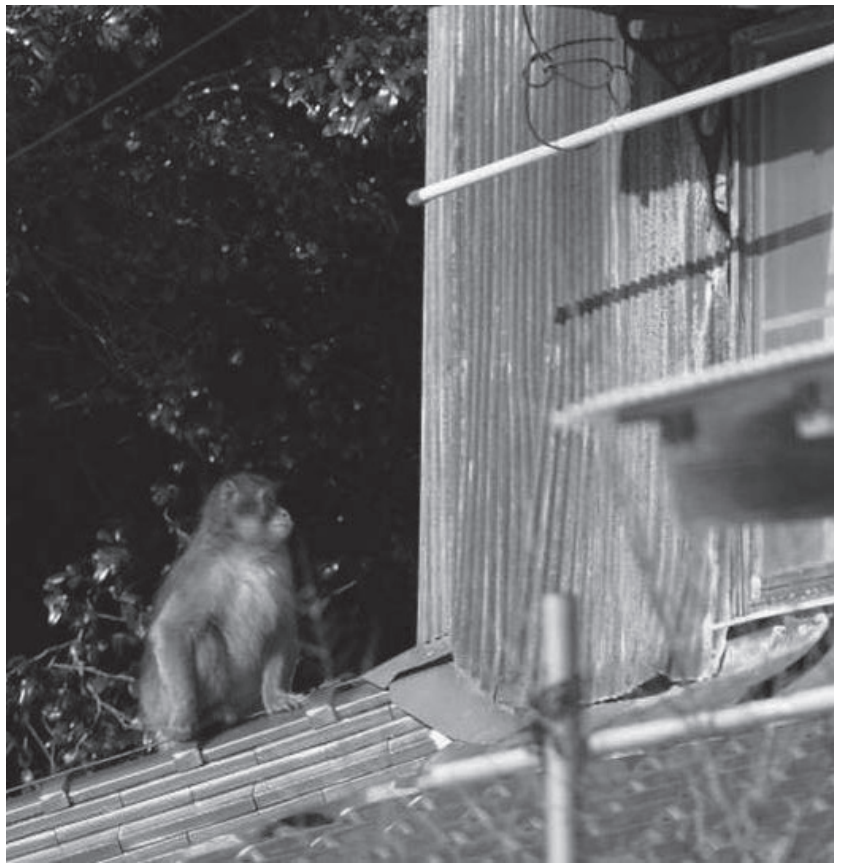

図 1 住宅地へ出没したサル

並びに狩猟の適正化に関する法律」（以下，鳥獣保護管理法） に変更となった。

今回の鳥獣保護管理法の改正で, 都道府県知事の許可により, 住居集合地域等に出没した野生動物に対し麻酔銃捕獲ができる ようになった [2]。

麻酔銃は, 野生動物調査業者, 野生動物を対象に研究を行つ ている大学や研究機関, 動物園, サファリパーク, 動物保健所 などで使用されている。麻酔銃は産業銃であるため，使用目的 によって許可が異なり, 理解しにくい部分もある。そこで, 今 後, 住居集合地域等で捕獲対応を求められた場合に必要な許可, 麻酔銃の特性, 使用方法, 想定される問題点などについて整理 を行った。

\section{住居集合地域等で使用する麻酔銃の種類と特性}

麻醉銃は, 麻酔薬の入った投薬器（注射筒）を空気圧で射出 する銃である。過去には，火薬を用いた銃が主流であったが発 射音の大きさから動物を驚かせたり，発射圧力調整の難しさの ため命中時の生体への影響（骨折や筋肉組織の損傷）が多いな どの理由から [3]，あまり使用されなくなった。空気圧を用 いたガス式麻酔銃は発射音が火薬式麻酔銃と比べてきわめて小 さく，発射圧力の調整もしやすいことから住宅集合地域等で使 用に適している。

麻醉銃は, ピストル型およびライフル型のタイプに分けられ

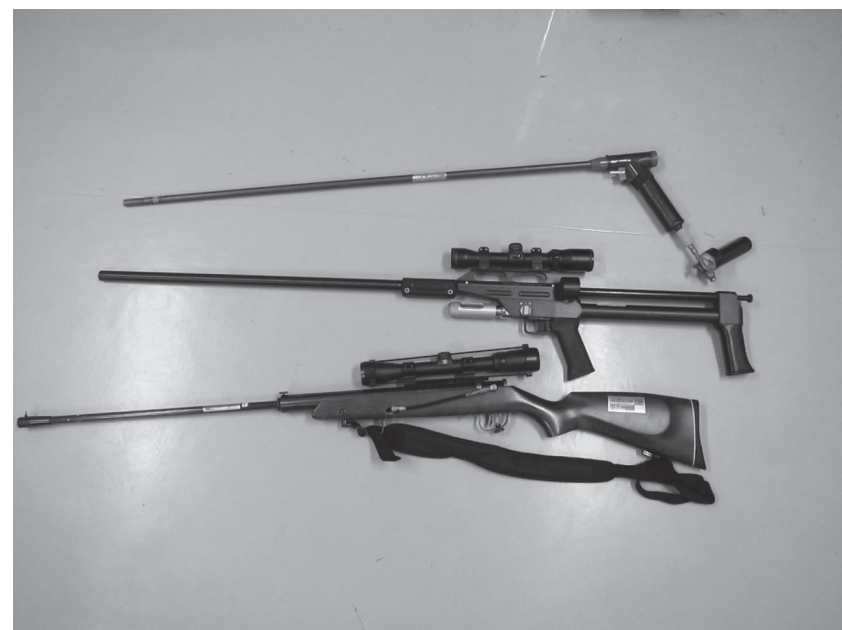

図 2 麻酔銃の種類

上：ピストル型 Telinject 社製，中：ライフル型 Dan Inject 社製, 下 : ライフル型 Telinject 社製

る（図 2)。ピストル型は，小型で取回しがよく，瞬時の発射 に適している。また，ライフル型と比較して，発射圧力が弱い ため対象動物へ与える影響も少ない。ライフル型は, 射程距離 が長く威力がある。スコープやドットサイト（光学照準器）を 用いることで命中率は上がる $[4]$ 。麻酔銃は，日頃より練習 して扱いに慣れておくことが重要である。銃の空気ガスの圧力 と命中する距離との関係を熟知しておく。距離計を使って距離 の感覚を養っておくことも重要である $[3,5]$ 。

投薬器は, $1.5 \mathrm{ml}, 3 \mathrm{ml}, 5 \mathrm{ml}, 10 \mathrm{ml}$ など様々な薬液量が入 る規格の製品が販売されている（図 3）。5 ml を超える大きな サイズの投薬器は, 重く, 飛距離が短くなる上, 風などの影響 を受けやすく，命中率が悪い。住宅集合地域で使用の場合は $1.5 \mathrm{ml}$ または $3 \mathrm{ml}$ の規格の投薬器の命中率が高く, 使用に適し ていると思われる。使用する投薬器の針は，大型獣のゾウやキ リン用から，小型獣のタヌキやキツネ用まで様々な規格の製品 が市販されており，動物種に合わせて選択する。

\section{麻酔銃所持に必要な許可や手続き}

麻酔銃を所持するには，銃刀法に基づき管轄する都道府県公 安委員会（管轄する都道府県警察署生活安全課が空口）から審 査を受けて許可を受けねばならない。申請者は，禁治産者，犯 罪歴, アルコールや薬物の依存, 精神状態, 認知症, 性格など について審査が行われる。また，ガンロッカー等頑丈な保管庫 で管理する必要がある。年 1 回，管轄する警察署による銃検 查が行われ, 改造の有無, 麻酔銃使用者の健康状態やアルコー ル依存の有無，性格が口頭で確認される。また，麻酔銃の保管 


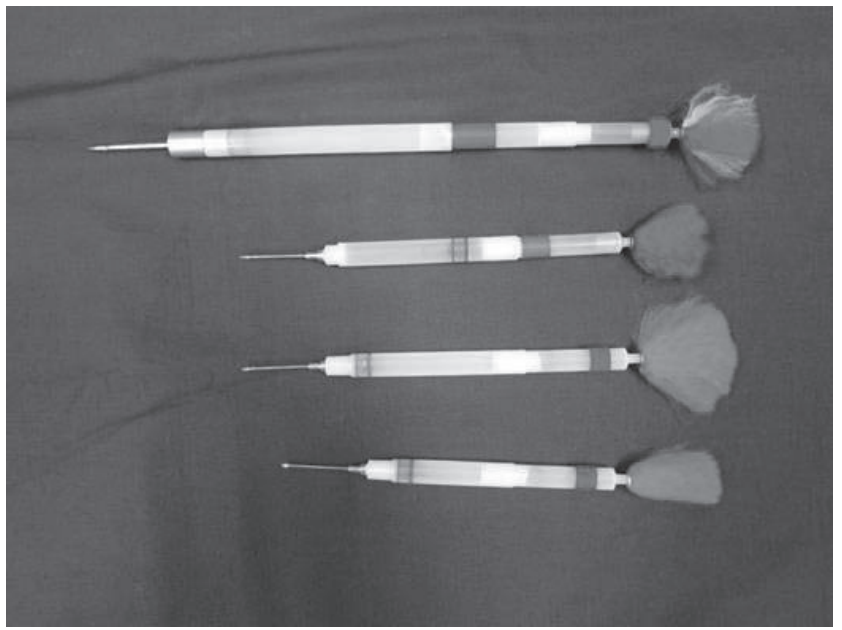

図 3 麻酔銃投薬器

上： $5 \mathrm{ml}$ Telinject 社製，中上：3ml Telinject 社製，中下 $3 \mathrm{ml}$ Dan Inject 社製，下：1.5 ml Dan Inject 社製

場所の位置情報, 管理状況についての報告が求められる。これ らは, 猟銃の検査内容と同じである。その一方で麻酔銃は産業 銃であるため, 猟銃の所持に必要とされている筆記試験および 実技試験が課せられず，銃の基本的な扱いを修得していない者 であっても警察の審査さえ通れば所持および使用が可能であ る。また, 猟銃は 3 年に 1 回, 更新手続きが必要であり経験 者講習, 技能講習, 専門医による精神疾患が無いことについて 診断書，使用実績の提出等が求められるが，麻酔銃にこのよう な手続きはない。猟銃は使用実績がない場合，警察からいわゆ る「眠り銃」と判断され没収される場合があるが, 麻酔銃は使 用実績がなくても没収されることはない。また，猟銃は「一 銃一許可制」で, 許可を取った者しか所持銃に触れることは認 められておらず，他の者は決して触ることができない。しかし 麻酔銃は，一つの銃を複数の者が使用することが認められてい る。麻酔銃所持許可申請の際に, 人命救助等に従事する者とし て届出済証明書に登録すれば, 所持者の監督の下, 複数の登録 者が麻酔銃を使用することができる。人命救助等に従事する者 は, 警察から審査を受けない。すなわち, 麻酔銃には厳重に管 理する義務が求められていながら, 使用に関わる知識や技術は 個人の力量に任されるといった不整合性が認められる。そのた め, 法律改正を論拠とする安易な導入と使用により, 思わぬ事 故が誘発されるおそれがある。今後, 住居集合地域等で麻酔銃 を使用する捕獲従事者は, 麻酔銃の構造や安全使用についての 研修を受講する必要があると考えられる。

\section{捕獲許可}

これまで野生動物の捕獲の許可は, 都道府県（有害鳥獣駆除 においては委譲されている場合は市町村許可）から学術捕獲許 可, 有害鳥獣駆除捕獲許可を受ける必要がる。また猟期中, 狩 猟の認められた場所で狩編鳥獣を捕獲する場合, 都道府県の許 可で捕獲することができる。新たに施行した鳥獣保護管理法に よる住居集合地域等へ侵入した動物の麻酔銃捕獲は, 都道府県 知事から捕獲許可を得て捕獲を実施する。

動物園などの飼育個体やエキゾチックペットの逃走は, 所有 者がいるため, 管理責任は所有者にあり，鳥獣保護管理法で定 める野生動物, 無主物の捕獲にはあたらないため許可を受ける 必要がない。しかし, 日本に生息している野生動物の場合, 出 没した個体が野生個体なのか飼育個体なのか判断が困難な場合 も考えられる。捕獲後, 飼育動物か野生動物の判定は, 出没地 域において捕獲した個体の飼育許可登録の有無の確認, 遺伝 子検査による出生した地域個体群の判定において判断される [6]。

\section{野生動物の麻酔銃捕獲で用いる鎮静・麻酔薬の種類と許可}

野生動物の捕獲のための麻酔薬として, 塩酸ケタミン（ケタ ラール第一三共プロファーマ）が使われることが多いが, 本薬 剂は麻薬指定されている（2007 年 1 月 1 日施行）。麻薬及び 向精神薬取締法第 3 条第 1 項の規定により, 野生動物に使用 する場合, 麻薬研究者の許可が必要である [7]。麻薬研究者 の許可を得れば, 塩酸ケタミンの購入および使用が可能となる。 一方, 開業獣医師や動物園獣医師, 保健所獣医師が使用する塩 酸ケタミンは, 飼育個体に使用するため麻薬施用者の許可が必 要である。この場合は, 野生動物に捕獲目的では使用すること はできないため, 注意が必要である。なお, 傷病鳥獣個体の治 療が目的の場合は使用可能である。塩酸ケタミンは, 重量金庫 等力ギをかけた堅固な設備に保管することが義務づけられてい る。また, 購入量, 使用量, 在庫量について厳密な管理が求め られ, 年 1 回, 麻薬年間受渡届を都道府県に提出し, 検査を 受けなければならない。野生動物の捕獲のための麻酔には, 一 般的に, 塩酸ケタミンに $\alpha-2$ 作用薬の塩酸メデトミジンか塩 酸キシラジンを混合して使用する。混合麻酔は, 塩酸ケタミン の量を少なくすることができる。また, 塩酸ケタミン単独で使 用した場合, 筋弛緩が不十分であり全身の痤攣や強直がしばし ば認められるが， $\alpha-2$ 作用薬を併用した場合，これら副作用 の発現を減らすことができる。また $\alpha-2$ 作用薬の拮抗薬であ るアチパメゾールを使用できる点がメリットである。塩酸ケタ ミン, 塩酸メデトミジンおよび塩酸キシラジンの 3 種の薬品に ついては, 鳥獣保護管理法第 36 条に規定する危険猟法に該当 
表 1 野生動物の捕獲に使用する鎮静・麻酔薬の特徵と関係法規

\begin{tabular}{|c|c|c|}
\hline 薬剤名 & 薬効・特徴 & 法規 \\
\hline 塩酸ケタミン & $\begin{array}{l}\text { 強力な鎮静作用を有し, 他の麻酔薬と比較し呼 } \\
\text { 吸系および循環系に対する影響が少ない。安全 } \\
\text { 域が広い麻酔薬であるため, 従来から幅広い野 } \\
\text { 生鳥獣で使用されている。市販のケタミンは, } \\
\text { 50mg/ml と濃度が低く, 投薬量が多くなるため, } \\
\text { 原末ケタミ年方用いて調整した高濃度のケタミ } \\
\text { ン溶液を用いるとよい。 }\end{array}$ & $\begin{array}{l}\text { 麻薬及び向精神薬取締法（昭和 } 28 \text { 年法律第 } 14 \text { 号）第 } 2 \\
\text { 条第 } 1 \text { 号に規定する麻薬に指定 } \\
\text { 医薬品医療機器等法第 } 44 \text { 条に基づく劇薬に指定 } \\
\text { 麻酔銃を使用する場合であって, } 1 \text { 発射 ( } 1 \text { 投薬器) 当た } \\
\text { り 5,700mg 以下の施用量であれば鳥獣保護管理法第 } 36 \\
\text { 条の危険猟法には該当しない }\end{array}$ \\
\hline 塩酸メデトミジン & $\begin{array}{l}\text { 強力な鎮静, 鎮痛, 中枢性筋弛緩作用を有する。 } \\
\text { 塩酸ケタミンと併用する。濃縮調整を必要とす } \\
\text { る場合がある。 }\end{array}$ & $\begin{array}{l}\text { 医薬品医療機器等法第 } 44 \text { 条に基づく毒薬又は劇薬に指定 } \\
\text { 麻酔銃を使用する場合であって, } 1 \text { 発射 ( } 1 \text { 投薬器) 当た } \\
\text { り 4,560mg 以下の施用量であれば鳥獣保護管理法第 } 36 \\
\text { 条の危険猟法には該当しない }\end{array}$ \\
\hline 塩酸キシラジン & $\begin{array}{l}\text { 鎮静, 鎮痛, 中枢性筋弛緩作用を有する。塩酸 } \\
\text { ケタミンと併用する。濃縮調整を必要とする場 } \\
\text { 合がある。 }\end{array}$ & $\begin{array}{l}\text { 医薬品医療機器等法第 } 44 \text { 条に基づく劇薬に指定 } \\
\text { 麻酔銃を使用する場合であって, } 1 \text { 発射 ( } 1 \text { 投薬器) 当た } \\
\text { り 6,840mg 以下の施用量であれば鳥獣保護管理法第 } 36 \\
\text { 条の危険猟法には該当しない }\end{array}$ \\
\hline
\end{tabular}

しない。ただし, 投薬器 1 本に充填する薬液量の濃度には上限 が定められており, 施用量が超える場合は, 危険猟法の許可を 取る必要がある（表 1 ）。また, 上記， 3 種以外の薬品におい ても毒物及び劇物取締法, または医薬品医療器等法によって毒 薬, または劇薬に指定されているもの, それ以外であっても薬 品類を使用する場合, 危険猟法に該当する可能性が高い。鳥獣 保護管理法第 37 条に基づく危険猟法の許可が必要である。環 境省より許可を受ける必要がある。

\section{麻醉銃射撃に必要な技術}

麻酔銃は, 標的となる個体の筋肉量の豊富な部位, 慰部, 大 腿部, 上腕部に向けて, 発射する。適切な発射圧は, 動物まで の距離や傾斜, 風向き, 風速によって変化する。そのため動物 の位置, 姿勢, 動きを予想し発射圧を瞬時に決定しなければな らない。確実に的中させるためには, 高度な技術と経験が必要 であり, 常にトレーニングを積んでおくことが重要である。投 薬器が命中し, 確実に麻酔薬が体内に注入された場合, 麻酔の 効果は, 通常 $5 \sim 10$ 分で現れ始める。投薬器命中後, 動物は その場にとどまっていることは少なく, 驚いて逃走することが 多い。その場合, 逃走方向を記録し, 捜索方向を決定する。捜 索は, 複数の人間で対応することが望ましい。個体発見後, 麻 酔導入が不十分な場合もある。麻酔薬の追加投与をすぐに行え るように, 予備の投薬器は, 常に準備しておく。また, 迅速に 動物を保定するため, ロープやタモ網, 麻袋等を準備しておく べきである $[5]$ 。

\section{捕獲後の検査および問題点}

住居地域等へ侵入した動物の捕獲は, 緊急性が高いため, 迅
速に対応することが重要である。しかし, 許可や捕獲体制を組 むことに時間を要す可能性が高く, その結果, 捕獲の失敗や, 人身被害を防ぎきれない可能性も想定される。そのため, 迅速 に捕獲ができるよう, 行政は事前に体制を組み, シュミレーショ ンしておくことが重要である。

捕獲完了後, 捕獲個体が, 野生個体であるか飼育個体である かをチェックする必要がある。種判定, 性別, 年齢区分 (老齢, 成熟, 若齢, 幼齢), 体格の計測, 体重 (栄養状態) など記録 しておく。また, 血液などを採取し, 遺伝子検査を実施するこ とで, 外来種（交雑個体）の判定や出生地域を判定できる可能 性もある。捕獲個体は, 原則, 人身被害を起こす可能性が高い 危険個体であるため, 安楽殺による処分が実施されることにな る。

しかし, 近年, 動物愛護の思想から, 殺処分に反対する世論 が強まり, 捕獲個体を飼育する例もある。人々の感情は, 動物 の捕獲前と捕獲後で大きく変わることがある。麻酔銃捕獲後, 一時的に檻へ搬入された状況になると，殺処分することを拒む 感情へと変わることがしばしば認められる。特にマスコミ等に よる報道があると, 殺処分反対の意見が行政へ集中し, 飼育す る方向へ方針転換される。野生動物の飼育は, 動物福祉や感染 症の問題がある上, 飼育施設の整備や人件費・䬲代など費用の 負担も大きいため, 絶滅が危惧されている種を除き, 飼育目的 が明確でない限り, 奨励されない。例えば, 有害駆除で野生二 ホンザルを 1 頭捕殺するのに報償費が行政から従事者に支給さ れながら,一方で, 飼育で行政負担が増えることは行政内で自 己矛盾が発生し問題となる。行政や関係機関は, 捕獲後の方針 を明確にし，いつでも市民等に説明できるよう，考え方や説明 資料を準備しておくことが重要である。 


\section{今後求められる麻酔銃捕獲に従事する人材}

住居集合地域等で麻酔銃捕獲する際, 経験がほとんどない捕 獲従事者は, 捕獲に失敗する可能性が高く, 事故を誘発する恐 れが高い。したがって, 山間部等において, すでに対象種に対 して捕獲実績のある者が従事すべきである。また, 従事者には, 捕獲対象動物の生態や行動を熟知し, かつ捕獲作業において, 全体の作業を統括できる人材が望ましい。野生動物の捕獲は, 知識や技術ばかりでなく, 全体の指示系統が曖昧であると失敗 する可能姓が高くなる。

これら専門的な技術や知識を有する人材は, 野生動物調査業 者, 専門に研究を行っている大学や研究機関等に所属している。 しかし, 人材が豊富に在籍しているわけではなく, 早急な対応 は難しい。一方，麻酔銃を保管している施設には，動物園・サ ファリパークや動物保健所がある。しかし, 野生個体を捕獲し た実績のある職員は極めて少ない。したがって, 今の日本には, 野生動物による人身被害を迅速に解決するため, 捕獲などに対 応できる人材が充足されているとは言えない状況にある。環境 省は，麻酔銃捕獲に必要なマニュアル [8] を作成した。今後 は人材確保のために研修を行うなどして, 野生動物問題を迅速 かつ確実に解決する体制を構築することが必要である。

\section{引用文献}

1. 警察庁. 2012. 銃砲刀剣類所持等取締法. http://law.e-gov.
go.jp/htmldata/S33/S33HO006.html（2015 年 11 月 1 日ア クセス). 警察庁, 東京.

2. 環境省. 2014. 鳥獣の保護及び管理並びに狩編の適正化に関 する法律. http://www.env.go.jp/press/17875.html（2015 年 11 月 1 日アクセス). 環境省, 東京.

3. Kreeger TJ. 2002. Handbook of Wildlife Chemical Immobilization. International Ed., $412 \mathrm{pp}$., Wildlife pharmaceuticals Inc., Colorado.

4. West G, Heard D, Caulkett N. 2007. Zoo Animal \& Wildlife Immobilization and Anesthesia, 719pp., Blackwell Publishing, Iowa.

5. 森光由樹. 2012. 捕獲と標識技術. 野生動物管理一理論と技 術一 (羽山伸一, 三浦慎吾, 梶 光一, 鈴木正嗣 編), pp.171193. 文永堂出版, 東京.

6. 森光由樹. 2015. 法改正で期待される麻酔銃捕獲の成果と課 題〜アーバインワイルドライフ問題解決に向けて〜. 野生動 物と社会 3: 35-40.

7. 厚生労働省. 2007. 麻薬及び向精神薬取締法. http://www. mhlw.go.jp/bunya/iyakuhin/yakubutura nyou/kanren-tuchi/ mayaku/18.html (2015 年 11 月 1 日アクセス). 厚生労働省, 東京.

8. 環境省. 2016. 住居集合地域等における麻酔銃の取り扱いに ついて（市街地や集落に出没した野生鳥獣への対応のため に), 19 pp., 環境省, 東京. 


\title{
The Safety Control of Anesthetic Guns When Used for Invading Wildlife in Urbanized Areas and the Role of Veterinarians
}

\author{
Yoshiki MORIMITSU* \\ University of Hyogo, Wildlife Management Research Center, 940 Sawano, Aogaki-cho, Tanba-shi, Hyogo 669-3842, Japan
}

[Received 6 October 2015; accepted 4 September 2016]

\begin{abstract}
Conflicts between wild animals and humans have been increasing during the recent years, resulting in damage to human environments and infrastructure as well as injuries to humans. In urban areas, capturing the wild animals is a difficult task because, by law, firearms cannot be used. As a method for rapidly incapacitating and capturing these animals, it has become legal to use tranquilizer guns, as they are non-lethal, and there is little danger of damage to the property. Capturing via tranquilizer gun is a safe method; however, operational problems remain. Because tranquilizer guns are drug delivery systems and not firearms, written tests and practical exams for the use of tranquilizer guns are not imposed. A person who does not have basic firearm training can still use the guns, as long as he/she passes police inspection. Because there are various problems in the positioning and operation of tranquilizer guns in the amended law, there is an immediate need to create user manuals and to formulate rules to prevent accidents.

Key words: tranquilizer guns, urbanizes area, urban wildlife, wildlife capture, Wildlife Protection and Proper Hunting Law — Jpn J Zoo Wildl Med 21(3): 91-96, 2016

* Corresponding author : Yoshiki MORIMITSU (E-mail: morimitsu@wmi-.hyogo.jp)
\end{abstract}

